\title{
THE Gd-Fe CONDENSED FILMS (STRUCTURE AND PROPERTIES)
}

\author{
V. Prysyazhnyuk (D), O. Mykolaychuk (D) \\ Ivan Franko National University of Lviv, \\ Departments for Metal Physics, \\ 8, Kyrylo $\&$ Mefodiy St., Lviv, UA-79005, Ukraine
}

(Received 15 September 2020; in final form 13 November 2020; accepted 17 November 2020; published online 23 December 2020)

\begin{abstract}
Amorphous films of compounds of the Gd-Fe system have been obtained using the method of thermal evaporation on fluoroplastic substrates. The substrate carrier temperature was $293 \mathrm{~K}$. The increase in the temperature of substrates or annealing of films carrier lead to the increase in the amount of the polycrystalline phase. The width of explored films was 50-200 nanometers. The study of the structure of the films was made on electron microscope UEMV-100K with use of high-temperature attachment PRON-2. Magnetic measurements were made on a vibrational magnetometer. The field magnetization vector was parallel to a film plane. The peak saturating field was $300 \mathrm{kA} / \mathrm{m}$. Structure and magnetic properties of films and bulk samples of the Gd-Fe system $\left(\mathrm{GdFe}_{2}, \mathrm{GdFe}_{5}\right.$ and $\left.\mathrm{Gd}_{2} \mathrm{Fe}_{17}\right)$ were analyzed. Loops of magnetic hysteresis under the influence of a small external field were obtained. The value of the coercive force was measured. It decreases at the formation of an amorphous film in comparison with bulk samples.
\end{abstract}

Key words: Gd-Fe, binary compound, thin film, amorphous state, magnetic properties, coercive force, hysteresis curve.

DOI: https://doi.org/10.30970/jps.24.4704

\section{INTRODUCTION}

Thin layers of rare-earth element-iron type intermetallic compounds are interesting due to their magnetic properties. These properties are strongly influenced by structural features of these compounds. For example, in the Gd-Fe system there are many structural types which have been studied recently. It is also necessary to note the significant influence of the methods and conditions of evaporation of films on the formation of their structure.

The considerable interest in the studies of the structure of the $\mathrm{Gd}_{2} \mathrm{Fe}_{17}$ films is caused by their peculiarity among other rare-earth metal-iron type compounds $\left(R_{2} \mathrm{Fe}_{17}\right)$. This peculiarity consists in the existence in equilibrium of two variants of structure phases, which are quite close in composition to $\mathrm{Gd}_{2} \mathrm{Fe}_{17}$. Moreover, one of these phases exists with an excess of $\mathrm{Fe}$ in equilibrium with $\alpha-\mathrm{Fe}$, and the other exists with a shortage of $\mathrm{Fe}$ in equilibrium with a compound similar to $\mathrm{GdFe}_{5}$. The possibility of the existence of many phases in equilibrium suggests a variety of structure and substructure formations in the films depending on the technological conditions of their deposition.

\section{DETAILS OF EXPERIMENT}

Films of binary compounds of the Gd-Fe system were obtained via the procedure of thermal vacuum vaporization of the polycrystalline mix material of the corresponding composition. The films $5-50$ $\mathrm{nm}$ thick were deposited on $\mathrm{NaCl}$ cleavage, then $\mathrm{NaCl}$ was dissolved in water. Some part of the films was picked up at once on copper grids for the electron diffraction research. The temperature of the substrates was fixed at $300 \mathrm{~K}$ and $500 \mathrm{~K}$. For structural studies, electron microscope UEMV$100 \mathrm{~K}$ and high-temperature attachment PRON-2 were used. The angular dependence of the atomic factors of electron scattering by atoms of gadolinium and iron was analyzed.

\section{RESULTS AND DISCUSSION}

The electron diffraction studies of the $\mathrm{Gd}_{2} \mathrm{Fe}_{17}$ films precipitated at $T_{\mathrm{S}}=300 \mathrm{~K}$ prove that these condensates are amorphous [1]. It has been established that when the thin films are heated, the first phase of crystallization consists of $\alpha$-Fe crystallites; their sizes increase as temperature rises. This is proven by the decrease in the half-width of the diffraction peaks in electron diffraction patterns and also is indicated by the estimations of the sizes of crystallites on the electronmicroscopic images. With further rises in temperature (over $100 \mathrm{~K}$ higher than the temperature of the beginning of the $\alpha$-Fe crystallization), the crystallization of the Gd concentrates amorphous matrix starts, and as a result, $\mathrm{Gd}_{6} \mathrm{Fe}_{23}$ crystallites are formed (structural type $\mathrm{Gd}_{6} \mathrm{Fe}_{23}$, space group $F m-3 m$ ). Crystallization of the amorphous $\mathrm{Gd}_{2} \mathrm{Fe}_{17}$ films is completed by the formation of a polycrystalline film of $\alpha$-Fe and $\mathrm{Gd}_{6} \mathrm{Fe}_{23}$.

The appearance of the $\mathrm{Gd}_{6} \mathrm{Fe}_{23}$ phase is not unexpected as in most $\mathrm{Gd}-\mathrm{Fe}$ systems. In addition, even in bulk samples in a Gd-Fe system, the $\mathrm{Gd}_{6} \mathrm{Fe}_{23}$ phase is always present when efforts are made to synthesize compounds with the high abundance of $\mathrm{Fe}\left(\mathrm{GdFe}_{5}\right.$, $\mathrm{Gd}_{2} \mathrm{Fe}_{17}$ ) without special technologies.

A significantly different picture is observed in the 


\section{PRYSYAZHNYUK, O. MYKOLAYCHUK}

phase formation kinetics of the $\mathrm{Gd}_{2} \mathrm{Fe}_{17}$ films obtained by vacuum deposition on a heated substrate. In the range of the substrate temperatures from $T_{\mathrm{s}}=400 \mathrm{~K}$ to $T_{\mathrm{s}}=500 \mathrm{~K}$, amorphous films are detected. At $T_{\mathrm{s}}=$ $500 \mathrm{~K}$, these films become amorphous-crystalline. With a further rise in the substrate temperature, the fraction of the polycrystalline phase grows. The interpretation of the electron diffraction peaks has shown that the polycrystalline films consist of three phases: $\mathrm{Gd}_{2} \mathrm{Fe}_{17}(60$ percent) with the $\mathrm{Th}_{2} \mathrm{Ni}_{17}$ structural type ( $f_{1}$-phase), $\mathrm{Gd}_{2} \mathrm{Fe}_{17}$ (30 percent) of the $\mathrm{Th}_{2} \mathrm{Zn}_{17}$ structural type $\left(f_{2^{-}}\right.$ phase) and some (about 10 percent) $\mathrm{GdFe}_{5}$ of the $\mathrm{CaCu}_{5}$ structural type. The unit cell of the hexagonal modification of $\mathrm{Gd}_{2} \mathrm{Fe}_{17}$ compound is modeled on the basis of the diffraction data using the crystallographic computer program PowderCell $(a=8.50 \AA$ A and $c=8.35 \AA)$.

\begin{tabular}{|l|c|c|c|}
\hline Compound & $\mathrm{GdFe}_{2}$ & $\mathrm{GdFe}_{5}$ & $\mathrm{Gd}_{2} \mathrm{Fe}_{17}$ \\
\hline Coercive force & $H, \mathrm{kA} / \mathrm{m}$ & $H, \mathrm{kA} / \mathrm{m}$ & $H, \mathrm{kA} / \mathrm{m}$ \\
\hline Bulk & 2.1 & 3.0 & 4.1 \\
\hline Amorphous film & 1.2 & 1.5 & 2.1 \\
\hline Polycrystalline film (the heated substrate) & 3.5 & 5.2 & 6.1 \\
\hline Polycrystalline film (annealing) & 3.6 & 5.1 & 6.0 \\
\hline
\end{tabular}

Table 1

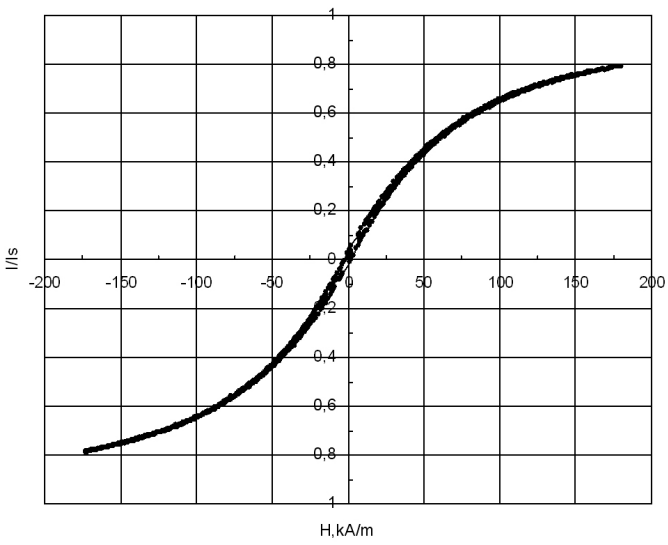

Fig. 1. Hysteresis curve for bulk $\mathrm{GdFe}_{2}$

The appearance of these phases in the $\mathrm{Gd}_{2} \mathrm{Fe}_{17}$ films indicates the capability to initiate the process of the emergence of microregions enriched and depleted in iron. This mechanism of film formation leads to the mutual blocking of the growth of $f_{1^{-}}$and $f_{2}$-phase crystallites. This determines the possibility of the existence of an amorphous state in the $\mathrm{Gd}_{2} \mathrm{Fe}_{17}$ intermetallic compound, and also causes high thermal stability of the amorphous state in the films precipitated at room temperature. When the films are deposited on heated substrates, the diffusion mobility of the adsorbed atoms increases and the density of the crystallites increases, in which the longrange order and the crystal structure of the $f_{1}$ and $f_{2}$ are formed.

The locations of diffraction peaks have not changed. This indicates that the formed structures do not change over time, and there is no evidence of oxidation. Comparing the intensity of the maxima, it is possible to observe a minor change in the phase content. The content of the hexagonal $\mathrm{Gd}_{2} \mathrm{Fe}_{17}$ compound has decreased (60 percent to 50 percent). The content of

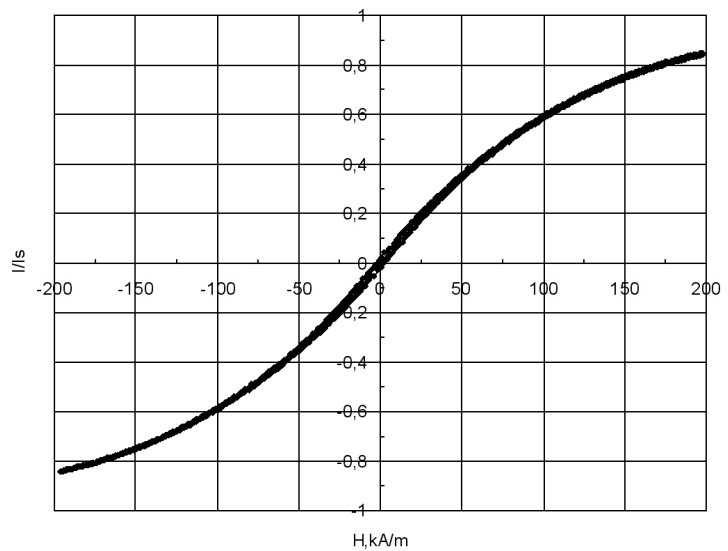

Fig. 2. Hysteresis curve for bulk $\mathrm{GdFe}_{5}$

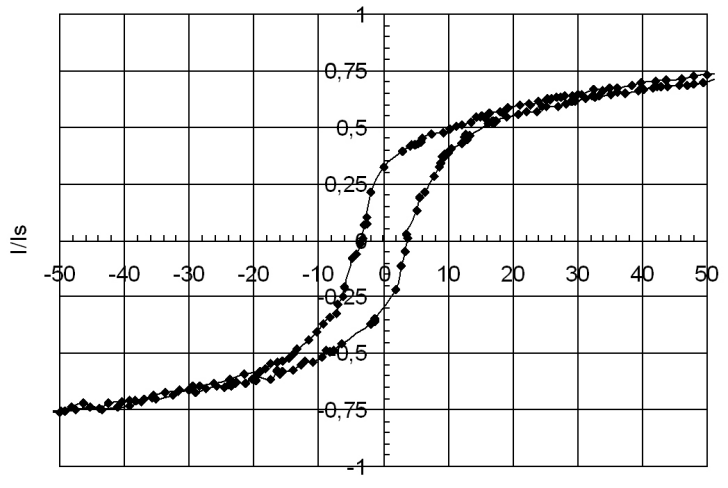

$\mathrm{H}, \mathrm{kA} / \mathrm{m}$

Fig. 3. Hysteresis curve for polycrystalline film $\mathrm{GdFe}_{2}$

the rhombohedral $\mathrm{Gd}_{2} \mathrm{Fe}_{17}$ compound has increased (30 percent to 40 percent). The only content which has not changed is the percentage of the hexagonal $\mathrm{GdFe}_{5}$ phase (10 percent). 


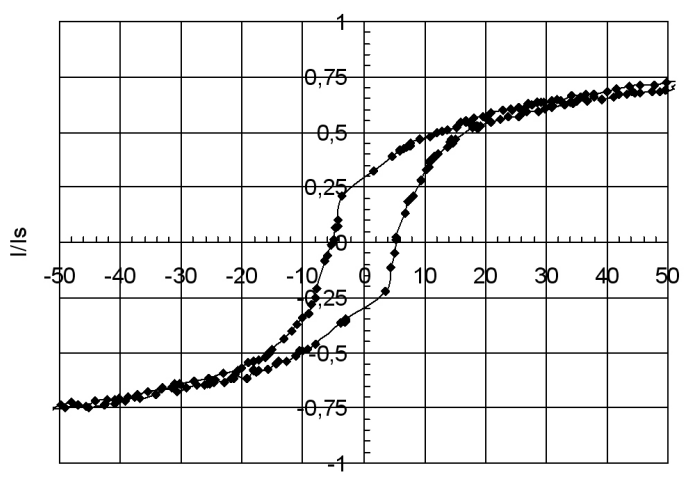

$\mathrm{H}, \mathrm{kA} / \mathrm{m}$

Fig. 4. Hysteresis curve for polycrystalline film $\mathrm{GdFe}_{5}$

We obtained loops of magnetic hysteresis for bulk and thin-film samples (Figs. 1-4) [2]. They confirm that the analyzed materials belong to the class of magnetically soft ferromagnets [3-5]. They are characterized by a narrow loop of magnetic hysteresis and, thus, the work of an external field inducing the magnetization reversal is small. Also, it is necessary to pay attention to the differences in the nature of hysteresis curves for bulk and thin-film samples of all compounds of the given system.

Table 1 shows the coercive force for amorphous and polycrystalline films as well as for bulk samples. The coercive force decreases with the formation of amorphous films, in comparison with bulk samples. This is caused by the lack of a long-range order in amorphous materials and, consequently, by a much smaller magnetic anisotropy. The formation of a polycrystalline phase in films leads to an increase in magnetic hardness. This results from the fact that the magnetization is measured along film surfaces. It is known that in films flat domains exi- st, which are much easier magnetized along rather than perpendicularly to the surface [6-8]. The influence of the relative content of iron in the compounds on the magnetic properties of the films was observed as well. It was also found that the value of the coercive force does not depend on the way the film crystallizes, either in the course of a film's formation on a heated substrate or during the annealing of amorphous films after they are obtained.

\section{CONCLUSION}

- The $\mathrm{Gd}_{2} \mathrm{Fe}_{17}$ films precipitated at $T_{\mathrm{s}}=300 \mathrm{~K}$ prove that these condensates are amorphous. Crystallization of amorphous $\mathrm{Gd}_{2} \mathrm{Fe}_{17}$ films is completed by the formation of a polycrystalline fi$\operatorname{lm}$ of $\alpha-\mathrm{Fe}$ and $\mathrm{Gd}_{6} \mathrm{Fe}_{23}$.

- The $\mathrm{Gd}_{2} \mathrm{Fe}_{17}$ films precipitated at $T_{\mathrm{s}}=500 \mathrm{~K}$ prove that these condensates are amorphouscrystalline: $\mathrm{Gd}_{2} \mathrm{Fe}_{17}$ (60 percent) of the $\mathrm{Th}_{2} \mathrm{Ni}_{17}$ structural type ( $f_{1}$-phase), $\mathrm{Gd}_{2} \mathrm{Fe}_{17}$ (30 percent) of the $\mathrm{Th}_{2} \mathrm{Zn}_{17}$ structural type ( $f_{2}$-phase) and some (about 10 percent) $\mathrm{GdFe}_{5}$ of the $\mathrm{CaCu}_{5}$ structural type.

- The studied compounds and their films belong to the class of soft magnetic materials.

- Coercive force decreases when amorphous films are formed, in comparison with bulk samples.

- The formation of a polycrystalline phase in films makes them more magnetically hard.
[1] V. Prysyazhnyuk, O. Mykolaychuk, Func. Mater. 20, 64 (2013); https://doi.org/10.15407/fm20.01.064.

[2] V. Prysyazhnyuk, O. Mykolaychuk, J. Phys. Stud. 23 2701 (2019); https://doi .org/10.30970/jps .23.2701.

[3] M. Zinkevich, N. Mattern, H. J. Seifert. J. Phase Equilib. 21, 385 (2000); https://doi.org/10.1361/1054971007 70339923.

[4] M. A. Cerdeira et al., J. Optoelectron. Adv. Mater. 6, 599 (2004).

[5] H. Dohnomae, J. Phys. Soc. Jpn. 62, 759 (1993); https:
//doi.org/10.1143/JPS J.62.759.

[6] A. S. Andreenko, S. A. Nikitin, Phys.-Usp. 40, 581 (1997); https://doi.org/10.1070/PU1997v040n06ABE H000245.

[7] K. H. J. Buscho, M. Brouha, J. W. M. Biesterbos, A. G. Dirks, Physica B+C 91, 261 (1977); https://do i.org/10.1016/0378-4363(77) 90194-2.

[8] L. T. Baczewski et al., Acta Phys. Polon. A 83, 629 (1993); https://doi.org/10.12693/APhysPolA.8 3.629.

\title{
КОНДЕНСОВАНІ ПЛІВКИ Gd-Fе (СТРУКТУРА ТА ВЛАСТИВОСТІ)
}

\author{
В. Присяжнюк, О. Миколайчук \\ Лъвівсъкий націоналъний університет імені Івана Франка, \\ вул. Кирила і Мебоділ, 8, 79005 Львів, Украӥна
}

Аморфні плівки подвійних сполук системи $\mathrm{Gd}-\mathrm{Fe}$ отримано методом термічного випаровування на фторопластові підкладки. Температура підкладки змінювалася в інтервалі температур 300-400 K. Підвищення температури підкладки або відпал плівок приводили до збільшення частки полікристалічної фази. Товщина досліджуваних плівок становила 50-200 нм залежно від їхнього призначення 
(структурні дослідження або магнітні дослідження). Перевіряли структуру плівок на електронному мікроскопі УЭМВ-100К з використанням високотемпературної приставки ПРОН-2. Магнітні вимірювання проводили на оригінальному вібраційному магнітометрі. Вектор намагніченості поля був паралельний до площини плівки, максимальне насичувальне поле $300 \mathrm{KA} /$ м. Виміряно магнітні характеристики плівок та масивних сполук системи $\mathrm{Gd}-\mathrm{Fe}\left(\mathrm{GdFe}_{2}, \mathrm{GdFe}_{5}\right.$ i $\left.\mathrm{Gd}_{2} \mathrm{Fe}_{17}\right)$. Отримано петлі магнітного гістерезису та температурні залежності магнітного насичення для масивних сполук та плівок $\mathrm{GdFe}_{2}$ i $\mathrm{Gd}_{2} \mathrm{Fe}_{17}$, визначено величину коерцитивної сили для цих сполук. Установлено, що під час формування аморфних плівок коерцитивна сила зменшується порівняно з масивними зразками. Це зумовлено відсутністю дальнього порядку в аморфних матеріалах і, як наслідок, набагато меншою магнітною анізотропією, що своєю чергою спричиняє невелике коерцитивне поле. Формування полікристалічної фази у плівках приводить до того, що наші зразки стають більш магнітотверді, навіть порівняно з масивними зразками. Ця особливість пояснюється тим, що намагніченість плівок вимірювали вздовж їхньої поверхні. Також установлено що для величини коерцитивної сили немає значення, як відбувається кристалізація плівки: чи в процесі формування самої плівки на підігріті підкладки, чи в процесі відпалу аморфних плівок після їх отримання.овані в наночастинці під дією йонізувального випромінювання, мають найбільшу ймовірність виходу за її межі.

Ключові слова: Gd-Fe, подвійна сполука, тонка плівка, аморфний стан, магнітні властивості, петля магнітного гістерезису, коерцитивна сила. 